\title{
Collective Action in the Management of a Tropical Dry Forest Ecosystem: Effects of Mexico's Property Rights Regime
}

\author{
Natalia Mariel Schroeder • Alicia Castillo
}

Received: 8 June 2012/Accepted: 26 October 2012/Published online: 13 November 2012

(C) Springer Science+Business Media New York 2012

\begin{abstract}
Dilemmas of natural resources governance have been a central concern for scholars, policy makers, and users. Major debates occur over the implications of property rights for common resources management. After the Mexican Revolution (1910-1917), land was distributed mainly as ejidos conceived as a hereditary but unalienable collective form of property. In 1992, a new Agrarian Law was decreed that allows individual ownership by removing various restrictions over the transfer of land. Scholars have examined the reform mainly focusing on land-tenure changes and environmental fragmentation. This study examines how the new ownership regime is affecting collective decision-making in ejidos located in a tropical dry forest (TDF) ecosystem. Information on decision-making processes before and after the 1992 reform was gathered through 52 interviews conducted in four ejidos selected along a gradient including agricultural, cattle-raising, and TDF use. The new individualized land property system reduced collective action in ejidos but did not trigger it. Collective action responses to the 1992 reform were buffered by self-organization each ejido already had. Heterogeneous users who shared a short history and showed little understanding of TDF and low dependence on its resources seemed to explain why ejidos have not been able to share a sense of community that would shape the construction of institutions for the collective management of forest
\end{abstract}

N. M. Schroeder $(\bowtie)$

Instituto Argentino de Investigaciones de las Zonas Áridas (IADIZA), CONICET, CC 507, 5500 Mendoza, Argentina

e-mail: natalias@mendoza-conicet.gob.ar

N. M. Schroeder · A. Castillo

Centro de Investigaciones en Ecosistemas, Universidad Nacional Autonoma de Mexico, Antigua carretera a Patzcuaro 8701, Apartado Postal 27-3 (Sta Ma. Guido), 58190 Morelia, Mexico resources. However, when a resource is scarce and highly valuable such as water the same users showed capacities for undertaking costly co-operative activities.

Keywords Property rights - Collective action . Tropical dry forest . México

\section{Introduction}

Property rights are crucial in understanding problems of natural resource management and governance (Agrawal 2001, 2007; McKean 2000; Ostrom 2001). Due to both its social and natural histories, Mexico presents a singular setting for the study of the development and function of local institutions and collective action regarding natural resources. As a consequence of the Mexican Revolution and the socio-political history of the XX Century until 1992, most agricultural and forested lands in Mexico were distributed to peasant holdings through two communal tenure systems: Agrarian indigenous communities (which recognized pre-Hispanic communal rights) and ejidos, which were conceived as "the collective subject of land distribution" which responded to the poor landless peasants who fought in the Revolution (Warman 2001, p. 55). These properties technically belonged to the federal government, but ejidos were conceived as a hereditary but unalienable collective form of land-tenure (Sarukhán and Larson 2001). According to the Agrarian Reform Law, each ejidatario (peasant, ejido member) received a parcel whose size depended on terrain type and vegetation cover with an allotment for urban settlement areas. An important element of ejidos is the communal land allotted for the use of all registered families, managed through a decision-making structure which until present includes the ejido Assembly 
(considered the main authority), and a committee (known as the Comisariado Ejidal) elected at the Assembly endowed with executive responsibilities. Ejidos have been acknowledged as shells that protect social-ecological systems (Alcorn and Toledo 1998; Toledo 1996). For more than 70 years, Mexico has employed a mixed system of property rights (Ostrom 2001) that can be described as a co-governance system (Agrawal 2007) since it combines governmental control of lands through implementing local collective management arrangements for the thousands of agricultural and forestry rural communities. Until 1991, more than half the country's continental territory (53\% corresponding to 103.3 million ha) fell under one of these two common property regimes (Warman 2001).

As part of neoliberal economic integration policies with North America in 1992 (later NAFTA; Toledo 1996), a new Agrarian Law was decreed that allows individual ownership of parcels to members of ejidos by removing various restrictions over the transfer of land and creating a legal avenue to convert ejidos into private property. That is, although before ejidatarios had rights over resource use in their assigned parcels, after the reform the federal government launched PROCEDE (Program for Certification of Ejido Rights and Titling of Urban Plots) through which individual ejidatarios can now fully own their parcels, common lands, and urban plots. The main objective of PROCEDE has been to provide land-tenure security to ejidatarios through individual or collective titles (Braña and Martínez 2005). Before the 1992 reform, ejidatarios could neither hire labor nor leave their lands for a period longer than two years without risking their rights as ejidatarios. Lands and membership rights (which included voting rights, individual usufructuary rights to parcels, and a share in the common land) could not be sold to outsiders; they could only be transferred through inheritance (Warman 2001). After obtaining ownership titles through the 1992 reform ejidatarios were given the right to sell, rent, sharecrop, or mortgage individual parceled land. Also, with $75 \%$ approval from the ejidatarios at the assembly, they can fully privatize an ejido, including commons lands (DOF 1992). Researchers who have examined the impact of the 1992 reform have mainly focused on land-tenure changes (if land has been privatized or not) and to environmental fragmentation caused by land-use changes (Luers and others 2006; Assies 2008; Barsimantov and others 2010; Perramond 2008; Farley and others 2012). However, questions regarding how collective action evolved through time and how the new ownership regime has affected collective decision-making in ejidos have received little attention.

The effect of the 1992 Agrarian Reform Law on decision-making processes regarding resource management may be particularly relevant in the context of ecosystems with high levels of biodiversity, where ecological consequences might be greater due to land fragmentation. One such ecosystem is the Tropical Dry Forest (TDF), which is the predominant type $(60 \%)$ of tropical vegetation in Mexico (Trejo and Dirzo 2000). These forests harbor about $19 \%$ of Mesoamerica's endemic vertebrate species (Flores and Gérez 1994) and nearly $60 \%$ of Mexican endemic flora (Rzedowsky 1991). Due to a highly seasonal rainfall pattern, most tree species in TDF are deciduous, small statured $(10 \mathrm{~m})$, have a low diameter $(10 \mathrm{~cm})$ and a high density of lianas and stems (some spiny) that makes access to the forest difficult (Maass and others 2005). Agricultural policies, particularly during the 1970s and 1980s, considered tropical forests as "unused lands", which could only be productive when transformed (SEMARNAT 2002). There was a National Commission for the clearing of vegetation areas in charge of making "useless" lands into agricultural and pasturelands ("productive" lands). This is recognized as one of the main causes of deforestation in tropical areas of Mexico (Paré 1995). TDF areas were particularly affected (Challenger 1998). In 1990, only $27 \%$ of the original TDF in Mexico still existed, $50 \%$ was categorized as degraded, and $23 \%$ as completely transformed (Trejo and Dirzo 2000). It should be noted that Mexico has been acknowledged as having developed successful examples of sustainable community forest management (Bray and Merino 2004; Velázquez and others 2001). In most cases, however, these examples are in temperate forests, there are some in tropical rain forests but examples in TDF are very scarce (Merino 2004). Most successful strategies are also found in indigenous communities with a strong cultural identity (Boege 2008). At present, nevertheless, most rural people in Mexico are mestizo (a mix between indigenous and Spanish descendants). In this context, this is the first study that aims to understand how the 1992 land ownership law reform affected collective action in ejidos in a TDF area. Our main objective was to document collective decisionmaking processes in four ejidos located in a TDF region with a particular focus on natural resource management before and after the 1992 law reform. It should be emphasized that TDF is regarded here as a resource system (following Ostrom 2009) that provides ecosystem services (Maass and others 2005) including land (to be used for agriculture or cattle-raising), timber and non-timber forest products, and water (Castillo and others 2005).

\section{Methods}

Study Area

The TDF ecosystem along the Jalisco coast has been recognized as particularly relevant in Mexico because of its 
high biodiversity and endemism (Ceballos and García 1995; Trejo and Dirzo 2000). It is also one of the better studied sites of the American continent (Noguera and others 2002) due to the creation of the Chamela Biological Research Station in 1971 and the presence of the Chamela-Cuixmala Biosphere Reserve decreed in 1993, which covers 13,142 ha (Ceballos and others 1999). However, most TDF is outside the protected area and belongs to ejidos (in the municipality La Huerta, where the reserve is located, $79 \%$ of lands belong to ejidos; INEGI 2001). Due to colonization and land-use policies, most ejidos in the area were created between 1950 and 1975 (Castillo and others 2005) and lands have been highly transformed mainly for cattle-raising, and for agriculture (Fig. 1). Forest exploitation is low, although 162 plant species have been identified as useful, 53 important for their wood (Bye and others 2002).

Topography changes from the coastal plain into the continent with consequences on soils, vegetation, and water availability (Maass and others 2005). Ejidos near the coast are made up of plain areas favorable for irrigation as well as low hills (altitude up to $800 \mathrm{~m}$ ) covered with TDF that characterize the transition into mountainous lands in the upper watersheds covered by temperate forest. The upland areas have a longer history of human occupation than the TDF coastal communities (Castillo and others 2009).

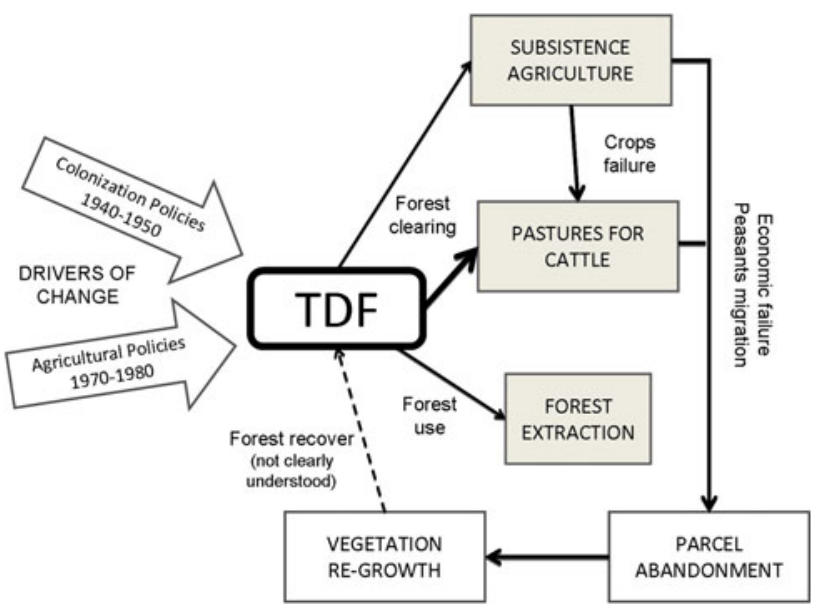

Fig. 1 General pattern of tropical dry forest (TDF) transformation in the Jalisco Coast. Due to the implementation of governmental policies in the past, TDF were greatly transformed into agricultural fields and pasturelands. After colonization and ejidos creation (1950-1975), TDF areas were open for subsistence agriculture. Due to low production and governmental incentives for land clearing and cattleraising, grasses were grown on parcels. Although economic gains were initially obtained, many peasants abandoned lands and sometimes emigrated. Vegetation re-growth and succession processes are not well understood. Extraction of timber and non-timber products has always occurred in vegetated lands in ejidos (for more information, see Burgos and Maass 2004; Maass and others 2005; Castillo and others 2005)

\section{Research Design and Data Collection}

We selected four ejidos as a multiple case study (Yin 2003) following a geographic-productive gradient from the coast into the mainland (Fig. 2). In Table 1, we summarize the principal features of the selected ejidos. La Fortuna consists mainly of plains with irrigation for commercial agriculture and pastures for cattle on hills. Due to its proximity to the ocean, this ejido also participates in tourism activities. Juan Gil Preciado has agricultural parcels on flat lands near a river, has a permit for forest use but is mainly dedicated to cattle-rising. Santa Cruz de Otates is almost completely dedicated to cattle-raising and Los Ranchitos participates equally in cattle production and forest extraction (also with a permit). This selection of ejidos allowed us to include the heterogeneity of ejidos present in this part of the Jalisco coast taking into direct consideration the different combinations of main land-uses.

Data was obtained through participant observation, semi-structured interviews, and workshops using a qualitative research approach (Taylor and Bogdan 1987; Denzin and Lincoln 2000). Through gaining participants' confidence and using open-ended questions, we listened to, recorded and examined people's visions in a very detailed

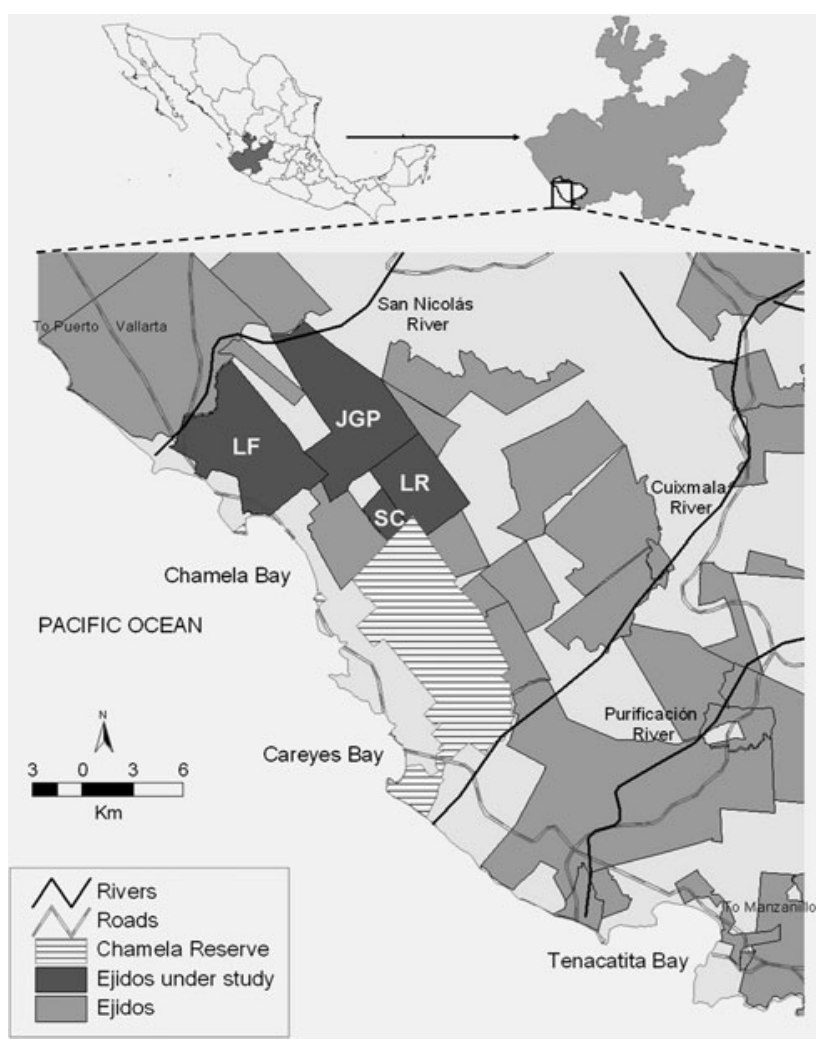

Fig. 2 Location of the ejidos under study in the Jalisco coast of México: La Fortuna (LF), Juan Gil Preciado (JG), Santa Cruz de Otates (SC) and Los Ranchitos (LR) 
Table 1 Main characteristics and number of interviews carried out on each of the four ejidos under study

\begin{tabular}{lllllr}
\hline Ejido (foundation year) & $\begin{array}{l}\text { Area } \\
\text { (ha) }\end{array}$ & $\begin{array}{l}\text { Number of } \\
\text { ejido members }\end{array}$ & $\begin{array}{l}\text { Certification year } \\
\text { (PROCEDE) }\end{array}$ & $\begin{array}{l}\text { Current main productive } \\
\text { activities }\end{array}$ & $\begin{array}{l}\text { Number of } \\
\text { interviews }\end{array}$ \\
\hline La Fortuna (1961) & 8,160 & 114 & 1998 & Agriculture, cattle-raising, tourism & 18 \\
Juan Gil Preciado (1967) & 7,077 & 101 & 1997 & Cattle-raising, TDF use \\
Santa Cruz de Otates (1968) & 1,460 & 40 & 2005 & Cattle-raising & 6 \\
Los Ranchitos (1968) & 3,350 & 54 & 1995 & TDF use, cattle-raising & 16 \\
\hline
\end{tabular}

${ }^{a}$ Program for certification of ejido rights and titling of urban plots (See text for details)

way. The strength of our analysis, therefore, is based not in proving hypothesis through quantitative data but in careful collection of qualitative evidence of participants' thinking and actions to clearly describe and comprehend their decision-making processes and natural resource management and how it has been affected by the 1992 Land Law Reform.

Through interviews we documented in a deep way the array of interests, motivations, and practices of ejidatarios on collective decision-making process within an historical context. Initially, we conducted interviews to two groups: past and present authorities (at the time of the study, 2005-2006) of the four ejidos. These interviewees acted as key informants due to their intimate understanding of ejidos' functioning. We then interviewed other ejido members (men and women who have lived in the ejidos permanently) selecting them through a "snowball" technique (Patton 1990) using saturation of data or "redundancy" (Baxter and Eyles 1997; Denzin and Lincoln 2000) to define sample size. A total of 52 interviews were conducted: 18 in La Fortuna, 16 in Juan Gil Preciado, 6 in Santa Cruz de Otates, and 12 in Los Ranchitos. All interviews were tape-recorded and fully transcribed. Qualitative analysis was carried out using the Atlas.ti sofware version 5.0 (http://www.atlasti.de). Through a line-by-line revision of transcripts, categories were created from the data with the aim of producing concepts that fitted the data, that is, ideas given by interviewees. Categories were linked and intertwined in diagrams or conceptual maps to construct interpretive texts. Observations obtained from the everyday cohabitation and informal conversations with the different actors were used to contextualize, complement and verify the information collected in interviews. Finally, we conducted three workshops in the four ejidos (one for $\mathrm{La}$ Fortuna, one for Los Ranchitos and one for Juan Gil Preciado and Santa Cruz de Otates). The purpose was to share the research results with the participants and residents, to collect any missing information and to validate the results through triangulation (Robson 1993; Baxter and Eyles 1997).

In the following section we present the narratives constructed and directly quote interviewees. In order to have an idea of the number of interviewees that shared a vision
(Seale 2000), we provide percentages of answers according to the total number of interviewees either in the four ejidos $(n=52)$ or in each ejido (Table 1$)$. It should be noted, however, that the semi-structured interview format was designed to facilitate open dialog to document participant perceptions regarding land and other resource use rules and agreements. Consequently, percentages cannot be read as if for all issues a $100 \%$ was reached. In those cases were percentages are not provided, it should be remembered that through triangulation, results come from interview responses as well as from data obtained through participant observation and workshops. As already emphasized in the qualitative research approach, the main interest is to document the multiple visions in relation to a phenomenon to construct a thorough understanding.

\section{Results}

\section{Collective Decision-Making Process}

We found that all matters concerning ejido function are discussed at assemblies and that decision regarding issues such as land distribution, cooperation agreements, conflict resolution, and also about common pool resources such as water and TDF as well as cattle were made collectively. Table 2 summarizes rules and agreements found in the four ejidos and the changes related to collective decisions after PROCEDE implementation. We defined "agreements" as all immediate decisions that affect an activity at a particular time, and "rules" as all long-term decisions that involve compliance with norms that require monitoring and penalties. Both types of collective action arrangements are formally recorded in the assembly proceedings.

\section{Before Land Certification (PROCEDE)}

At the time of the ejidos' establishment, each ejidatario was allocated a land parcel of 20 ha (average size). The remaining ejido land was established as common land. Over time, these common lands have been subject to different degrees of use and parceling. Since their establishment, seasonal agriculture was the main production activity 
Table 2 Agreements (A), rules (R), and penalties (S) before and after the 1992 Law Reform for the LF (La Fortuna) JGP (Juan Gil Preciado), SCO (Santa Cruz de Otates), and LR (Los Ranchitos) ejidos

\begin{tabular}{|c|c|c|c|c|c|c|c|c|}
\hline \multirow[t]{2}{*}{ Theme } & \multicolumn{4}{|c|}{ Before PROCEDE } & \multicolumn{4}{|c|}{ After PROCEDE } \\
\hline & LF & JGP & $\mathrm{SCO}$ & LR & $\mathrm{LF}$ & JGP & $\mathrm{SCO}$ & LR \\
\hline (R) Communal use of forest resources (small forestry permits) & & & & $\mathrm{x}$ & & & & \\
\hline (R) Distribution of work and profits (cattle-raising) & $\mathrm{x}$ & $\mathrm{x}$ & & $\mathrm{x}$ & & & & \\
\hline (A) Cattle and land distribution (cattle-raising) & $\mathrm{x}$ & $\mathrm{x}$ & & $\mathrm{x}$ & & & & \\
\hline $\begin{array}{l}\text { (R) Participation in construction and maintenance of water supply } \\
\text { system; distribution of water among ejidos }\end{array}$ & & $\mathrm{x}$ & $\mathrm{x}$ & $\mathrm{x}$ & & $\mathrm{x}$ & $\mathrm{x}$ & $\mathrm{x}$ \\
\hline (R) Payment of monthly fee for the water committee & & $\mathrm{x}$ & $\mathrm{x}$ & $\mathrm{x}$ & & $\mathrm{x}$ & $\mathrm{x}$ & $\mathrm{x}$ \\
\hline $\begin{array}{l}\text { (S) To pay (with money or work) if failure to comply with maintenance } \\
\text { work of water supply system }\end{array}$ & & $\mathrm{x}$ & $\mathrm{x}$ & & & $\mathrm{x}$ & $\mathrm{x}$ & \\
\hline (R) Notifying assembly when selling a parcel & $\mathrm{x}$ & $\mathrm{x}$ & $\mathrm{x}$ & $\mathrm{x}$ & & $\mathrm{x}^{\#}$ & $x^{\#}$ & $\mathrm{x}^{\#}$ \\
\hline (R) Paying debts and fines when selling a parcel & & $\mathrm{x}$ & & $\mathrm{x}$ & & $\mathrm{x}$ & & $\mathrm{x}$ \\
\hline (A) Conflict resolution & $\mathrm{x}$ & $\mathrm{x}$ & $\mathrm{x}$ & $\mathrm{x}$ & $\mathrm{x}^{\#}$ & $x^{\#}$ & $\mathrm{x}^{\#}$ & $\mathrm{x}^{\#}$ \\
\hline (R) Attend ejido assembly & $\mathrm{x}$ & $\mathrm{x}$ & $\mathrm{x}$ & $\mathrm{x}$ & $\mathrm{x}$ & $\mathrm{x}$ & $\mathrm{x}$ & $\mathrm{x}$ \\
\hline (S) Fines for absence & & $\mathrm{x}$ & & $\mathrm{x}$ & & & & $\mathrm{x}$ \\
\hline (S) No benefits from ejido & $\mathrm{x}$ & & & & $\mathrm{x}$ & & & \\
\hline (A) Distribution of common lands & $\mathrm{x}$ & $\mathrm{x}$ & $\mathrm{x}$ & & & & & $\mathrm{x}$ \\
\hline (A) Respect for everyone's allotment & & & & & $\mathrm{x}$ & $\mathrm{x}$ & & \\
\hline $\begin{array}{l}\text { (A) Compensation of common area distributed in accordance with } \\
\text { original allotment }\end{array}$ & & & & & & & $\mathrm{x}$ & $\mathrm{x}$ \\
\hline (A) The ejido can make use of the distributed common land & & & & & & & & $\mathrm{x}$ \\
\hline (A) Logging permit is for the ejido, but earnings are individual & & & & & & $\mathrm{x}$ & & $\mathrm{x}$ \\
\hline (R) Logging permit: \% of individual sales goes to the ejido & & & & & & $\mathrm{x}$ & & $\mathrm{x}$ \\
\hline
\end{tabular}

Penalties make reference to the rules to which they are related. Agreements, rules, and penalties that emerged, changed (\#) or were eliminated at least in one ejido after the 1992 reform are in bold type (See text for details)

in the four ejidos. Ejidatarios cut down TDF and set up individual parcels. The more important crop was maize, which was initially very profitable (Fig. 1). During this time (1960-1970), TDF exploitation in La Fortuna, Juan Gil, and Santa Cruz was mainly conducted individually, i.e., each ejidatario cutting trees from his/her parcel without a governmental forest permit. According to interviewees, forest timber was not valued: "Before, timber was not used as it should have been, because no one knew that it was something valuable, it was just cut down and burned." Almost half of interviewees (48 \%) in these three ejidos emphasized they had no forestry vocation. Some peasants from La Fortuna (22\%) also mentioned that outsiders exploited the fine woods. In Los Ranchitos, one interviewee acknowledged that forest timber was wasted in initial activities, but $33 \%$ agreed that later, logging became a communal activity through obtaining small governmental forestry permits using about $50 \mathrm{~m}^{3}$ of forest timber per year. The rule was that all ejidatarios ought to work in logging and all profits were to the ejido's general expenses, like those required for obtaining the final map of the ejido.

During the 1970s, peasant from La Fortuna, Juan Gil, and Los Ranchitos cleared forests and created pastures on common areas to raise cattle and formed Cattle-Raising Associations. They obtained support for the associations through governmental program sponsorship. Most ejidatarios at La Fortuna (72\%) and Juan Gil (69\%) agreed that few ejidatarios were interested in involvement in the associations, whereas $33 \%$ of interviewees at Los Ranchitos mentioned all ejido members participated. La Fortuna used two common areas (of 500 and 560 ha); Juan Gil Preciado used the plain areas of their three designated common lands (of 100, 120, and 800 ha) and Los Ranchitos used about 740 ha of theirs. The associations in La Fortuna and Juan Gil were the only collective use associations that were reported. During this communal management of pastures and cattle, specialized tasks (cattle management and milking cows) required a daily or monthly payment that came from the association's profits. The rest of the maintenance of the animals (bathing, looking after herds, and fixing fences) was divided among partners. A complete record of wages was kept that was then used to distribute annual profits and for the final distribution of cattle when an association was dissolved. Dissolutions occurred after 4 years of work in La Fortuna, 9 in Juan Gil, and 6 in Los Ranchitos. In the three ejidos almost half the interviewees $(48 \%)$ recognized internal 
corruption among association authorities and members as main driver for dissolution of the associations: "I was in charge of the corral and witnessed all the tricks, the calves that were stolen." Other significant factors in dissolution were animal mismanagement and internal disagreements that caused members to become worn out: "As we were all owners, there were individuals who wanted to command others, and that is not possible, having many generals in a battalion." Interviewees (61\% of interviewees at La Fortuna and $38 \%$ in Juan Gil) mentioned that livestock was distributed according to the accumulated wages; whereas more than half ejidatarios at Los Ranchitos (58 \%) expressed that all members received the same number of animals regardless of accumulated wages. Regarding land distribution, in La Fortuna this benefit was only for association members (expressed by $22 \%$ of interviewees), while in Juan Gil (81 \%) and Los Ranchitos (33\%) lands were reported as being distributed to all ejidatarios equally.

Ejidatarios from Santa Cruz never used their designated common land for collective use. Almost from the beginning they decided to distribute lands among all ejidatarios. As a consequence, ejidatarios did not recognize in interviews a common land area. They always referred to it as "my own common".

During the 1980's and for some time, government continued providing credits for cattle breeding but only for small groups or individuals. In Santa Cruz and Los Ranchitos, $44 \%$ of interviewees expressed that "there were other credits, but only for a few people." This was expressed as appearing that they were initially beneficial because of the low interest rates, but ultimately they were not because "cattle were already too expensive for us." In other cases, people formed groups to get bank loans but afterward each person took care of his/her own cattle on his/her own land: "You care for your cattle, she cares for hers, that is, together as a group, but not mixed up with the animals." In La Fortuna and Juan Gil, however, 35 \% of interviewees argued that people began to acquire individual loans during this time-a practice that continues to the present day.

By the mid 1980s, Juan Gil, Santa Cruz, and Los Ranchitos mobilized to resolve severe water scarcity for domestic and productive uses. The three ejidos organized to utilize water from a spring flowing on a hillside $18 \mathrm{~km}$ away. The ejidos received material and technical advice from government and contributed work using equitable labor hours "but with great pleasure, as water was a big problem." The social organization achieved by these ejidos was fundamental in resolving the water crisis. People in three ejidos (59\%) emphasized that rules concerning water transportation and distribution as well as maintenance of the system were agreed upon according to the size of each ejido: "From the beginning Juan Gil had twice the number of people than the other two ejidos and therefore it gets the amount of water accordingly." Regarding maintenance of the irrigation pipeline, Juan Gil designated two overseers, whereas in Santa Cruz and Los Ranchitos only one. To the present day, water committees from each ejido designate a delegate to fulfill these tasks. It is the responsibility of each committee to organize maintenance crews in the event of a pipeline failure, and to charge monthly maintenance fees to corresponding ejidatarios. The water committees keep a record of payments and submit reports at assembly meetings. Four ejidatarios $(11 \%)$ mentioned a penalty for failing to comply with the rule that requires maintenance to be provided when there is a pipeline issue. The penalty consists of paying the unpaid labor with cash or work: "in order to be even, so that there is no discord." It is important to note that this water supply system organized by the three ejidos has functioned for nearly three decades, from the 1980s until the present day.

Despite being considered as illegal practice until 1992, some $(33 \%)$ recognized there were land purchases and sale agreements: "Before (PROCEDE) anyone could buy land, you only needed to sign a certificate at an assembly in agreement with all ejidatarios; the buyer was made known, and he just continue paying." Thus, the rule required notification of the assembly when selling a parcel. In Juan Gil and Los Ranchitos the process for selling had two requirements: (1) people had to show that they had no debts to the ejido and (2) they had to pay a fee to sell. When there were land limit issues (both between ejidatarios and with outsiders) or issues with selling a parcel, $33 \%$ of ejidatarios mentioned that they solved those informally through internal agreements: "very simple, there was litigation in this limit, both parties came to the ejido authorities and it was agreed".

Since the formation of the ejidos, $52 \%$ of the ejidatarios acknowledged that attending assemblies was a main rule: "It (attendance) is the foundation of an ejido organization". Some ejidatarios (17\%) stated that in some cases penalties were enforced for not attending assemblies, including fines for each absence (Juan Gil and Los Ranchitos) or not receiving benefits from an ejido (La Fortuna). Although there were exceptions such as giving notice in advance for an absence or in the case of elderly members (Los Ranchitos).

\section{After Land Certification (PROCEDE)}

There was great variation in ejidos with regard to parcel allocation when PROCEDE was decreed (Table 1). First, $100 \%$ of ejidatarios of Santa Cruz agreed that due to initial field measurements errors in parcel allotments, some received more land than others. Second, $39 \%$ of peasant at La Fortuna, and $33 \%$ at Juan Gil recognized there was 
opportunism by people, who wanted to expand their lands: "As some lands were vacant and considered as wasted plots, some individuals began fencing and fencing". Finally, domestic purchases and sale agreements enabled some individuals to seize more parcels, which were mentioned by $33 \%$ of all interviewees. This contributed to the uneven individual parcel allocations within each ejido, especially in La Fortuna and Juan Gil, as emphasized in the following quote: "One ejidatario may have 500, 200, 100 or 80 ha; and we, the poor or lazy, still have 20 ha”.

As stated earlier, in La Fortuna, Juan Gil, and Santa Cruz, the ejido's common lands were assigned to individuals before PROCEDE intervention. Los Ranchitos, in contrast, decided the individual distribution at the moment of certification. Whereas ejidatarios of La Fortuna and Juan Gil seem to agree to respect ejidatarios individual lands (29\% of interviewees), in Santa Cruz and Los Ranchitos it was clear that common lands distribution for certification was adjusted in accordance with the original allotments for a more equitable distribution (72\% of interviewees). Two ejidatarios of Los Ranchitos recognized that the common lands assigned could be worked in the same way as their own, however, "at any point, the ejido can tell me they will remove wood from my parcel because it is needed for furniture for the Ejido House, or for anything else".

Juan Gil and Los Ranchitos have Forestry Permits granted by the Ministry of the Environment: Juan Gil for 10 years since 2001 and Los Ranchitos for 25 years since 1992. Every year forest technicians assign trees to be cut in different areas according to amount of wood authorized for the permit period. It should be noted that, although given to a whole ejido, permits are not used in a collective manner. Individuals cut and sell trees from their own parcels or from areas that may have originally been common. It seems clear that the agreement with regard to permit use is internal to each ejido (36\%): "For society the permit is communal, our agreement is internal, no one knows." The president of a Comisariado Ejidal is responsible for managing forest logging permits in an ejido. He must be informed of the sites where officials assign trees and determine who is eligible to receive a share of annual profits. He issues the guidelines and signs the permits for timber transportation and must also report the cost-benefits at the assembly. In both ejidos, $36 \%$ of interviewees said that a percentage of individual timber sales goes to each ejido's treasury. The logging permit caused some problems in Juan Gil Preciado. Participation in the use of the permit is limited in such a way that not everyone benefited from it. Some (31\%) argued that it was not profitable, as their investment was greater than the return: "This time I got six cubic meters, what am I going to do with that?" Also some lands had no "monte" (rural term for unused vegetated land) to profit from. Others (38\%) argued that a small, elite group managed the forestry permit. Those that have larger areas of usable land have the power to make decisions with regard to access and benefits. In Los Ranchitos, in contrast, half of them (50\%) emphasized that the activity benefits all ejido members, that is, the profits are distributed equally. Although $17 \%$ of ejidatarios also commented that the forestry permits were not always profitable. Forestry represents an important source of income in this ejido to this day, along with cattle breeding activities.

Cattle breeding, already individually managed in all cases, became a subsistence activity since the decline of agriculture in the 1990s. More than half of interviewees (53\%), nevertheless, explained this situation was mainly associated with rainfall shortage, which they perceived as having increased in recent years. Others (46\%) also identified both market price fluctuation of products and rural policies as responsible for the bad situation in rural areas. At that time, government loans, besides having been reduced, were often no longer suitable: "Before, it was very easy, some peasants got cattle and sold them and did not pay bank debts, now this is no longer so, there are credits, but with too many requirements." The whole scenario created a strong sense of production insecurity among ejidatarios. People did and do not have secure income sources. Almost half of interviewees (46\%) agreed that many people emigrate (mainly young people) in search of better opportunities. Some ejidatarios (23\%) mentioned that high levels of emigration have had a negative impact on attendance at ejido assemblies: "We are becoming a ghost ejido," as expressed by an interviewee in La Fortuna.

Another reason for low participation in assemblies is related to PROCEDE implementation. According to interviewees in Juan Gil (38\%) and Santa Cruz (67\%), attendance dropped because people felt more certain of their ownership rights after the land was certified. They no longer fear being deprived of their land and have abandoned their duties as ejidatarios: "Before, when we had no PROCEDE, all of us attended because it was always said that three absences would cause a parcel to be taken away; but now it is no longer so, we have a paper, and this paper protect us from being dispossessed of the land." Two ejidatarios in Juan Gil also mentioned that the ejidos were no longer able to impose fines for not attending assemblies after land certification.

After PROCEDE certification, mechanisms for selling changed substantially. The first step requires a formal announcement signed by ejido authorities. The new Agrarian Law established priorities regarding purchase eligibility. Family members of the seller (either the wife or children over 18 years) are given first priority for purchase. If no family members are interested in purchase then any ejidatario has second priority and finally, the "avecindados" (people who live in an urban settlement but have no land) are eligible. If after a period of one month, no interest is shown by those in the 
hierarchy of first priority, the ejidatario is authorized to offer the land to an outsider. This new rule was mentioned in the four ejidos. According to the law, the Comisariado Ejidal must be made aware of all land sales. Interviewees from Juan Gil and Los Ranchitos (21\% in total) emphasized that ejidatarios are aware they must notify the assembly when they want to sell a parcel: "Everyone is free to do whatever they want with their land, provided they take into account the assembly." In La Fortuna, however, $28 \%$ of ejidatarios mentioned that after the 1992 reform it was no longer mandatory to notify the assembly when selling a parcel. Also, some interviewees in this ejido (17\%) recognized that parcels close to the beach had high value constituting this an incentive for selling lands to "rich people" for private tourism enterprises.

Solving land conflicts also changed after the reforms. Boundary conflicts now involve an Agrarian Court, through "long and costly legal processes", as expressed in Juan Gil.

\section{Discussion}

Our study adds to the few existing studies regarding this important reform and its impacts. This case study shows the dynamics of collective action in a social-ecological system associated with TDF in which there are political pressures which cause difficulties for rural people to sustain their traditions, livelihoods, and earn a living (Maass and others 2005; Castillo and others 2005), which have been understudied from a socio-political viewpoint. Our findings demonstrate that, in relation to collective action, the 1992 reform law acted to facilitate the ongoing process of individualization of land management. Although our findings are place-specific, this case study elucidates problems related to trust building and maintenance among ejidos' members. We found that when rural people felt they were deceived, their response was to withdraw from collective action regardless of the theoretical benefits that working together might present. In the case of a scarce and vital common pool resource such as water, nevertheless, results were as consistent with Ostrom (1990). People collectively organized by constructing solid institutions and agreements. It has been acknowledged that México's impressive biodiversity is due in part to its historical communal landtenure system (Alcorn and Toledo 1998) that is now being privatized. In the following sections, we discuss the implications of these issues in more depth in relation to what other studies have found.

\section{Losing Collectiveness: The Role of the Property Reform}

Our main finding is that a radical change in the collective organization structure of ejidos did not occur as a direct result of the 1992 law reform and the implementation of PROCEDE. We discovered that efforts toward collective action were not only influenced by governmental incentives but also by groups of people who believed that working together would be beneficial as a result of mutual necessity. These collective efforts suffered a decline over time before 1992 due to problems such as corruption that led to individualistic attitudes and actions. The individualized land-tenure system promulgated in 1992 contributed to this phenomenon, but did not trigger it. In our research PROCEDE appeared as a driver for the break down of collective action which perpetuated and even encouraged the individualization process that had been occurring before its implementation.

Contrary to some predictions, studies have found that responses to the 1992 reforms did not follow a single path, but rather, were filtered by a diverse set of drivers unrelated to the policy reform that resulted in localized impacts with distinctive outcomes (Luers and others 2006; Assies 2008; Barsimantov and others 2010; Farley and others 2012). Evidence supporting this was also found in other land reform policy studies in other countries such as Kenya and India (Ensminger 1996; Jodha 1996). In a multi-case study in Quintana Roo (southeastern Mexico), it was found that while inland ejidos with strong base of communal-forestry management maintained larger proportions of common lands during certification, those ocean-front ejidos exposed to a rising land prices related to tourism expansion, showed high levels of parceling and increased land sales to outsiders (Barsimantov and others 2010). Also in Mexico, Vargas and others (2008) encountered a similar situation in ejidos with an ocean-front in Bahia de los Angeles (Gulf of California), where people were already selling or were willing to sell lands. Although in this case, an NGO initiated a program to mitigate the change in land-tenure simultaneously promoting community conservation areas. Similarly, in the case of La Fortuna, some ejidatarios recognized that high prices for lands with beach proximity were important incentives to sell lands. On the contrary, others studies in ejidos along the watershed of the Tijuana River in the northwest found that full land title was obtained in a range of settings, rather than primarily on land closest to urban zones with high land values (Farley and others 2012). Authors explained that, in this case, landtenure security appeared to play a larger role than the opportunity to sell the land.

Focusing on collective action changes, we consider that the ejidos' responses to the 1992 reforms were buffered by the level of self-organization that each ejido had developed previously. In La Fortuna, Juan Gil and Santa Cruz, we found little evidence of collective action even from their initial stages of ejido development. The few examples of collective work (as in the cattle rising associations) fell 
apart long before PROCEDE due to internal problems that eventually became the key factors behind the division of common lands in La Fortuna and Juan Gil. Our results suggest that PROCEDE accentuated the disinterest in collective action in the ejidos as it provided the legal framework to formalize individual property. This was evident by the repeated testimonies of low assembly attendance in Santa Cruz and Juan Gil Preciado emphasizing that now ejidatarios have certificates and there is no risk of land being taken away. Moreover, apparently in Juan Gil, enforcement of the penalty for absences was suspended since PROCEDE. Feelings that interest in ejido matters had decreased since 1992 reforms have also been found in a study conducted in the Yaqui Valley in the north of Mexico (Lewis 2002).

In contrast, Los Ranchitos developed from its establishement a relative more complex system of rules and agreements and was able to recognize and obtain collective benefits. We found that at the moment of land certification ejidatarios decided to divide the common areas, producing changes in their collective forest management. Some ejidatarios, however, still considered the common land as owned by the ejido and that the assembly has a right to use common lands when necessary by collective agreement. This may be showing that their collective practices have not been entirely lost. The internal division of common lands at the time of certification in this ejido may be explained by what neighboring ejidos were doing. At Los Ranchitos we found no evidence that the issue of low assembly attendance is due to PROCEDE implementation but it rather seems to be a consequence of the emigration process.

Our interpretation of self-organization as an important driver in the varying responses to the 1992 reform was reinforced when we analyzed how each ejido chose to certify their ejido lands (RAN 2012). Those ejidos that show low collective action such as La Fortuna and Juan Gil, parceled almost all their lands and obtained individual certifications (88.9 and $96.7 \%$, respectively). Moreover, the ejido La Fortuna decided to request "dominio pleno" (meaning complete possession) for 1000.51 ha, which is a direct means to achieve small private property always obtained with the endorsement of an ejido assembly (DOF 1992). In contrast, Santa Cruz and Los Ranchitos parceled and certified only the original parcels (about 20 ha for each ejidatario) corresponding to 59.8 and $57.37 \%$, respectively, while the remaining lands were certified as communal. It is important to note, however, that regardless of the legal status of land, the common land management practices are very different in the two ejidos. While Santa Cruz has not recognized common land since the creation of the ejido, in Los Ranchitos, as-mentioned previously, the common but divided lands continue to be available for the needs of the entire ejido.
Self-Governance: Attributes of Resources and Users

Regardless of particular responses to the 1992 reforms, the question of why these ejidos do not share a sense of community in shaping the development of institutions for the collective management of their resources remains. The likelihood of users engaging in collective action to selforganize is suggested to be strongly dependent on a combination of resources and users' attributes of the particularly resource system operating at specific spatial and temporal scales (Ostrom 2003). In this case study, we found a particular combination of attributes that discouraged collective action to varying degrees.

Ejidos in the southern part of the Jalisco coast were recently established and most people came from neighboring states. Ejidos were therefore constituted with heterogeneous groups who did not share a history or identity. They also had a poor understanding of the particular ecological characteristics of their TDF environment (Castillo and others 2005, 2009). While it is not always the case, it is widely acknowledged that communities that share a common identity and have strong social capital due to long periods of coexistence such as indigenous communities, are better able to deal with dilemmas regarding the commons (Ostrom 1990; Richards 1997; Berkes and Folke 1998; Barsimantov and others 2010). In our study, trust between ejido members, especially at La Fortuna and Juan Gil, was significantly weakened due to corruption which greatly affected their collective decision-making ability. The issue of distrust was a main contributor in weakening the internal negotiations in the cattle breeding associations that resulted in their dissolution. When a group is invaded by distrust and conflicts, it is unlikely that co-operative arrangements emerge or, if they exist, that they can be sustained (Trawick 2001; Pretty 2003).

The relatively more complex system of rules and agreements found in Los Ranchitos may be explained by analyzing their geographical-productive situation. Los Ranchitos is the most remote and more isolated among the four ejidos (Fig. 2). Also, it has the lowest economically active population (17\%), and has the highest percentage of residents receiving less than minimum wage [654 Mexican pesos per month (USD 51.3), INEGI 2010]. Households in Los Ranchitos are reported as mostly poor, where $32 \%$ do not receive social services (INEGI 2001). According to Agrawal (2007), poverty directly relates to the ability of users to generate the necessary resources and capacities to protect and regulate common pool resources. In Los Ranchitos, their relative isolation combined with the low availability of financial resources could have also favored social cohesion among ejidatarios, which facilitated the development of a more solid and stable social capital and co-operative institutional structure.

On the other hand, it has been argued that unless users recognize a resource system as providing them something 
essential for their livelihoods, they do not possess or can lack the motivation to incur into the costs of organizing and maintaining a self-governing system (Gibson and Becker 2000; Chhatre and Agrawal 2008; Ostrom 2009). Previous studies in the region determined that opening areas for farming was hard work for ejidatarios and at present they have a deeply rooted vocation for livestock and agricultural production. Ejidatarios are proud of the lands they turned into farming plots and pastured fields, and they perceive TDF as an obstacle to their production activities (Castillo and others 2005, 2009). In this sense, ejidatarios acknowledge TDF transformation as a relevant ecosystem service they get from it because it offers the possibility to carry out their main livelihood activities (Castillo and others 2005). The low value they give to TDF is related to a low immediate productive value (Ostrom 2007). There has not been an opportunity for ejidatarios to develop a living based on TDF use; only a few timber species have been exploited and only as a secondary activity (as a supplement to the livestock activity). Although in theory collective management of TDF could bring benefits to users, investing in the creation of a self-governance system to regulate their use in this case involves a high opportunity cost (Schlager and Ostrom 1992; McKean and Ostrom 1995; Dietz and others 2003; Ostrom and Nagendra 2006).

Interestingly, a contrary situation exists for water as a common pool resource. Water is a limiting factor in the TDF ecosystem as a result of seasonality and it is a vital resource for the main domestic and production activities. This resource is clearly perceived by ejidatarios as the most important ecosystem service (Castillo and others 2005, 2009; Maass and others 2005). Water has high value and, due to seasonal constraints to its access, there is a persistent concern for its long-term provision. Consequently, the benefits of having a system that secures a consistent water supply and its adequate quality for consumption is extremely relevant. After years of suffering water shortages and poor water quality, the need for the resource greatly exceeded the costs of investing in creating and maintaining a local institution that regulates it. This is one explanation as to why the organization for water transportation, its delivery and the maintenance of the pipeline system, involving three ejidos, has been sustained successfully. The findings that the same users are willing, in some settings, to undertake costly co-operative activities including monitoring are consistent with other field studies of resource use (Bray and Klepeis 2005; Ostrom and Nagendra 2006).

\section{Sustainability and TDF Future}

Maintenance of vegetation cover, especially in those areas relevant for biodiversity conservation and the delivery of ecosystem services, is crucial. On the Jalisco coast, according to recent analysis, ejidos around the biosphere reserve maintain 70-80 \% of TDF vegetation cover (Sánchez-Azofeifa and others 2009), although its quality is still unknown. The social panorama, however, combines low productivity of TDF, low economic value of timber and non-timber products, the absence of collective-choice rules for TDF management and heterogeneous user groups who share a short history and thus have a low attachment to the ecosystem. Consequently, these rural people have a superficial understanding of the resource system and a low dependence on TDF for their livelihood. All these attributes, embedded in a context of unfavorable public policies, seem to discourage conservation and sustainable TDF use. Based on our results and the experience gained after 10 years of conducting research in this area, crafting a sustainable management strategy requires at least focus on the following issues.

The motives behind the 1992 land reform policies imposed by global economics, and supported by the Mexican government, were to promote free market and private enterprises as the best ways to conserve lands, forests and water (Bray 1996). Although for some agricultural activities benefits may be associated with smaller parcels fully owned by individuals or families, for other activities parceling has not proven to promote sustainability (Ostrom 2001). It has been documented that for forest resources, communal governance often functions more successfully than private systems in terms of resources conservation, economic viability and social equity (Schlager and Ostrom 1992; McKean and Ostrom 1995; Bray and Klepeis 2005). In contrast to temperate and tropical rain forests, TDF regions present difficulties because of their low productivity and high variance in resource units on a given parcel. Another notable result of this study is that the existence of forested areas as common property is no guarantee that user groups will organize collectively. However, when essential resources (such as water in this case) are at stake, people developed collective decisionmaking processes, acted as partners and constructed effective, regulated local institutions. As emphasized by Ostrom (2007), there are no universal solutions. Crafting a TDF management strategy that combines individual and collective ownership with collective decision-making regarding strategic resources remains a great challenge.

In order to analyze and to modify current production activities in TDF, incentives and committed interventions with regard to capacity building are required. Providing information and technical assistance on the resource system is crucial for environmental governance (Bray 1996; Dietz and others 2003). In the instances of limited historic interaction with TDF systems, ejidatarios have not been able to construct the necessary understanding to deal with TDF management. However, people can acquire knowledge or 
capacity for constructing such understanding. Scientific information regarding TDF collected over 40 years includes nearly 600 scientific papers, 400 thesis, nine books and more than 140 book chapters (Pérez 2011) as a result of the university research station in this part of the Pacific coast of Mexico, that was mentioned earlier in this article. This extensive research needs to play a direct role. Expertise of scientists is another valuable asset that should be used through conducting participatory-action research or through training locals to use, monitor and construct ways to sustainable managing the resource system. Exploitation of timber and non-timber products, environmental services payments, promotion of ecotourism, or other innovations combining the beauty of the coastal landscapes and its particular features should be encouraged. Ejidos will likely not disappear (Warman 2001) or they will at the very least retain their benefits as collectives (Bray 1996). They, along with scientific, governmental and other local organizations must work together to open the possibility for a transition into a more sustainable management scenario.

Acknowledgments We would like to offer our immense gratitude to all interviewees that took part in the study. We also thank Lucía Martínez, Karin Troncoso, Gustavo Verduzco, Abel Verduzco, Salvador Araiza, Alejandra González Manjarres y Ana Castrejón for their support. To Nelly Horak and Miramanni M. Mishkin who provided valuable assistance with the English language; three anonymous reviewers and editors help to improve the manuscript. We would also like to acknowledge support from Fondo Mixto CONACYT-Jalisco \# 99050, and from OEA-LASPAU Fellowship (to N.S.).

Conflict of interest The authors declare that this research is in compliance with Mexico's current laws and that there is no conflict of interest.

\section{References}

Agrawal A (2001) Common property institutions and sustainable governance of resources. World Dev 29:1649-1672

Agrawal A (2007) Forests, governance, and sustainability: common property theory and its contributions. Int J Commons 1:111-136

Alcorn JB, Toledo VM (1998) Resilient resource management in Mexico's forest ecosystems: the contribution of property rights. In: Berkes F, Folke C (eds) Linking social and ecological systems. Management practices and social mechanisms for building resilience. Cambridge University Press, Cambridge, pp 216-249

Assies W (2008) Land tenure and tenure regimes in Mexico: an overview. J Agrar Change 8:33-63

Barsimantov J, Racelis A, Barnes G, DiGiano M (2010) Tenure, tourism and timber in Quintana Roo, Mexico: land tenure changes in forest ejidos after Agrarian Reforms. Int J Commons 4:293-318

Baxter J, Eyles J (1997) Evaluating qualitative research in social geography: establishing 'rigour' in interview analysis. Trans Inst Br Geogr 22:505-525

Berkes F, Folke C (1998) Linking social and ecological systems management practices and social mechanisms for building resilience. Cambridge University Press, Cambridge
Boege E (2008) El patrimonio biocultural de los pueblos indígenas de México. Instituto Nacional de Antropología e Historia, Comisión Nacional para el Desarrollo de los Pubelos Indígenas, México DF

Braña J, Martínez A (2005) El PROCEDE y su impacto en la toma de decisiones sobre los recursos de uso común. Gaceta ecológica 75:35-49

Bray BD (1996) Of land tenure, forests, and water: the impact of the reforms to article 27 on the Mexican environment. In: Randall L (ed) Reforming Mexico's Agrarian Reform. ME Sharpe, New York, pp 215-221

Bray DB, Klepeis P (2005) Deforestation, forest transitions, and institutions for sustainability in southeastern Mexico, 1900-2000. Environ Hist 11:195-223

Bray DB, Merino L (2004) Los bosques comunitarios de México. Logros y desafíos. Ford Foundation-The William and Flora Hewlett Foundation-SEMARNAT-FIU-CCMSS-Forest TrendsIIS-UNAM-CIDE, México DF

Burgos A, Maass JM (2004) Vegetation change associated with landuse in tropical dry forest areas of Western Mexico. Agric Ecosyst Environ 104:475-481

Bye R, Cervantes L, Rendón B (2002) Etnobotánica en la región de Chamela, Jalisco, México. In: Noguera FA, Rivera JHV, GarcíaAldrete AN, Quesada-Avendaño M (eds) Historia natural de Chamela Instituto de Biología. Universidad Nacional Autónoma de México, México DF, pp 545-559

Castillo A, Magaña A, Pujadas A, Martínez L, Godínez C (2005) Understanding the interaction of rural people with ecosystems: a case study in a tropical dry forest of Mexico. Ecosystems 8:630-643

Castillo A, Godínez C, Schroeder N, Galicia C, Pujadas A, Martínez L (2009) El bosque tropical seco en riesgo: Conflictos entre uso agropecuario, desarrollo turístico y provisión de servicios ecosistémicos en la Costa de Jalisco, México. Interciencia 34: $844-850$

Ceballos G, García A (1995) Conserving neotropical biodiversity, the role of dry forest in western México. Conserv Biol 9:1349-1356

Ceballos G, Székely A, García A, Rodríguez P, Noguera F (1999) Programa de Manejo de la Reserva de la Biosfera ChamelaCuixmala. Instituto Nacional de Ecología Secretaría de Medio Ambiente, Recursos Naturales y Pesca, México DF

Challenger A (1998) Utilización y conservación de los ecosistemas terrestres de México: Pasado, presente y futuro. Comisión Nacional para el Conocimiento y Uso de la BiodiversidadUNAM-Agrupación Sierra Madre del Sur SC, México DF

Chhatre A, Agrawal A (2008) Forest commons and local enforcement. Proc Natl Acad Sci USA 105:13286-13291

Denzin NK, Lincoln S (2000) Handbook of qualitative research, 2nd edn. Sage Publications, Thousand Oaks

Diario Oficial de la Federación (DOF) (1992) Ley Agraria. http://info4.juridicas.unam.mx/ijure/tcfed/12.htm?s. Accessed 4 Apr 2011

Dietz T, Ostrom E, Stern PC (2003) The struggle to govern the commons. Science 302:1907-1912

Ensminger J (1996) Culture and property rights. In: Hanna SS, Folke C, Maler KG (eds) Right to nature: ecological, economic cultural and political principles of institutions for the environment. Island Press, Washington DC, pp 179-205

Farley K, Ojeda-Revah L, Atkinson EE, Eaton-González BR (2012) Changes in land use, land tenure, and landscape fragmentation in the Tijuana River Watershed following reform of the ejido sector. Land Use Policy 29:187-197

Flores VO, Gérez P (1994) Biodiversidad y Conservación en México: Vertebrados, Vegetación y Uso del suelo. CONABIO, UNAM, México DF

Gibson CC, Becker CD (2000) A lack of institutional demand: why a strong local community in western Ecuador fails to protect its 
forest. In: Gibson CC, McKean MA, Ostrom E (eds) People and forests. Communities, institutions and governance. The MIT Press, Cambridge, pp 135-161

Instituto Nacional de Estadística, Geografía e Informática (2001) Principales Resultados por Localidad, Estados Unidos Mexicanos, XII Censo de Población y Vivienda, 2000. http://www.inegi. org.mx/est/contenidos/Proyectos/ccpv/cpv2000/default.aspx. Accessed 31 Mar 2011

Instituto Nacional de Estadística, Geografía e Informática (2010) Estadísticas históricas de México 2009. http://www.inegi.org. $\mathrm{mx} /$ prod_serv/contenidos/espanol/bvinegi/productos/integracion/ pais/historicas10/Tema6_Salarios.pdf. Accessed 31 Mar 2011

Jodha NS (1996) Property rights and development. In: Hanna SS, Folke C, Maler KG (eds) Right to nature: ecological, economic cultural and political principles of institutions for the environment. Island Press, Washington DC, pp 205-223

Lewis J (2002) Agrarian change and privatization of ejido land in Northern Mexico. J Agrar Change 2:401-419

Luers AL, Naylor RL, Matson PA (2006) A case study of land reform and coastal land transformation in southern Sonora, Mexico. Land Use Policy 23:436-447

Maass JM, Balvanera P, Castillo A, Daily GC, Mooney HA, Ehrlich P, Quesada M, Miranda A, Jaramillo VJ, García-Oliva F, Martínez-Yrizar A, Cotler H, López-Blanco J, Pérez-Jiménez A, Búrquez A, Tinoco C, Ceballos G, Barraza L, Ayala R, Sarukhán J (2005) Ecosystem services of tropical dry forests: insights from longterm ecological and social research on the Pacific Coast of Mexico. Ecol Soc 10:17

McKean MA (2000) Common property: what is it, what is it good for and what makes it work. In: Gibson CC, McKean MA, Ostrom E (eds) People and forests. Communities, institutions and governance. The MIT Press, Cambridge, pp 27-56

McKean M, Ostrom E (1995) Common property regimes in the forest: just a relic from the past? Unasylva 180:3-15

Merino L (2004) Conservación o deterioro: El impacto de las políticas públicas en las instituciones comunitarias y en las prácticas de uso de los recursos forestales. Instituto Nacional de Ecología (INE-SEMARNAT), México DF

Noguera F, Vega Rivera JH, Aldrete García AN (2002) Introducción. In: Noguera FA, Rivera JHV, García-Aldrete AN, QuesadaAvendaño M (eds) Historia natural de Chamela. Instituto de Biología, Universidad Nacional Autónoma de México, México DF, pp xv-xxi

Ostrom E (1990) Governing the commons: the evolution of institutions for collective action. Cambridge University Press, New York

Ostrom E (2001) The puzzle of counterproductive property rights reforms: a conceptual analysis. In: de Janvry A, Gordillo G, Platteau JP, Sadoulet E (eds) Access to land, rural poverty, and public action. Oxford University Press, New York, pp 129-150

Ostrom E (2003) How types of goods and property rights jointly affect collective action. J Theor Politics 15:239-270

Ostrom E (2007) A diagnostic approach for going beyond panaceas. Proc Natl Acad Sci USA 104:15181-15187

Ostrom E (2009) A general framework for analyzing sustainability of social-ecological systems. Science 325:419-422

Ostrom E, Nagendra N (2006) Insights on linking forests, trees, and people from the air, on the ground, and in the laboratory. Proc Natl Acad Sci USA 103:19224-19231

Paré L (1995) Transformación de los sistemas productivos y deterioro del medio ambiente en una región étnica del trópico veracruzano. In: Palos Juan (ed) Carton de Grammont H (ed) Globalización, deterioro ambiental y reorganización social en el campo. UNAM, México DF, pp 122-158

Patton M (1990) Qualitative evaluation and research methods. Sage Publications, Newbury Park

Pérez H (2011) Necesidades de información para el manejo de los socio-ecosistemas de la región Chamela-Cuixmala, Jalisco. Dissertation, Universidad Nacional Autónoma de México

Perramond EP (2008) The rise, fall, and reconfiguration of the Mexican ejido. Geogr Rev 98:356-371

Pretty J (2003) Social capital and the collective management of resources. Science 302:1912-1914

Registro Agrario Nacional (RAN) (2012) Padrón e Historial de Nucleos Agrarios (PHINA). http://phina.ran.gob.mx/phina2/. Accessed 24 Mar 2012

Richards M (1997) Common property resource institutions and forest management in Latin America. Dev Change 28:95-117

Robson C (1993) Real world research: a resource for social scientists and practitioner-researchers. Blackwell Publisher, Oxford

Rzedowsky J (1991) Diversidad y orígenes de la flora fanerogámica mexicana: una apreciación analítica preliminar. Acta Botánica Mexicana 15:47-64

Sánchez-Azofeifa A, Quesada M, Cuevas-Reyes P, Castillo A, Sánchez G (2009) Land cover and conservation in the area of influence of the Chamela-Cuixmala Biosphere Reserve, Mexico. Forest Ecol Manag 258:907-912

Sarukhán J, Larson J (2001) When the commons become less tragic: land tenure, social organization, and fair trade in Mexico. In: Burger J, Ostrom E, Norgaard RB, Policansky D, Goldstein BD (eds) Protecting the commons. Island Press, Washington DC, pp 45-69

Schlager E, Ostrom E (1992) Property-rights regimes and natural resources: a conceptual analysis. Land Econ 68:249-262

Seale C (2000) The quality of qualitative research. SAGE Publications, London

SEMARNAT (2002) Programa estratégico para conservar los ecosistemas y su biodiversidad. Secretaría de Medio Ambiente y Recursos Naturales, México DF

Taylor SJ, Bogdan R (1987) Introducción a los métodos cualitativos de investigación. La búsqueda de significados. Paidós, Barcelona

Toledo VM (1996) The ecological consequences of the 1992 Agrarian Law of Mexico. In: Randall L (ed) Reforming Mexico's Agrarian Reform. ME Sharpe, New York, pp 247-263

Trawick P (2001) Successfully governing the commons: principles of social organization in an Andean irrigation system. Hum Ecol 29:1-25

Trejo I, Dirzo R (2000) Deforestation of seasonally dry tropical forest: a national and local analysis in Mexico. Biol Conserv 94:133-142

Vargas MA, Ochoa F, Danemann GD (2008) Tenencia de la tierra y conservación de tierras privadas. In: Danemann GD, Ezcurra E (eds) Bahía de los Angeles: recursos naturales y comunidad. Línea base. SEMARNAT, INE, Pronatura Noroeste A.C. San Diego Natural History Museum, ciudad? México DF, pp 679-693

Velázquez A, Bocco G, Torres A (2001) Turning scientific approaches into practical conservation actions: the case of Comunidad Indígena de Nuevo San Juan Parangaricutiro, México. Environ Manag 5:216-231

Warman A (2001) El campo mexicano en el siglo XX. Fondo de Cultura Económica, México DF

Yin RK (2003) Case study research. Design and methods. Sage Publications, Thousand Oaks 